\title{
LINEAR AND NON-LINEAR ANALYSES OF CABLE-STAYED STEEL FRAME SUBJECTED TO SEISMIC ACTIONS
}

\section{Marko Đuran}

Professional paper / Stručni rad

Plan Plus d.o.o., Zagreb, MSc

Ivan Lukačević

University of Zagreb, Faculty of Civil Engineering, Ph.D

Corresponding author: ica@grad.hr

Darko Dujmović

University of Zagreb, Faculty of Civil Engineering, Full Professor

\begin{abstract}
In this study, linear and non-linear dynamic analyses of a cable-stayed steel frame subjected to seismic actions are performed. The analyzed cable-stayed frame is the main supporting structure of a wide-span sports hall. Since the complex dynamic behavior of cable-stayed structures results in significant geometric nonlinearity, a nonlinear time history analysis is conducted. As a reference, an analysis using the European standard approach, the so-called linear modal response spectrum method, is also performed. The analyses are conducted for different seismic actions considering dependence on the response spectrums for various ground types and the corresponding artificially generated accelerograms. Despite fundamental differences between the two analyses, results indicate that the modal response spectrum analysis is surprisingly consistent with the internal forces and bending moment distributions of the nonlinear time history analysis. However, significantly smaller values of bending moments, internal forces, and displacements are obtained with the response spectrum analysis.
\end{abstract}

Keywords: nonlinearity; seismic analysis; response spectrum; time history; cable-stayed steel frame

\section{LINEARNE I NELINEARNE ANALIZE OVJEŠENOG ČELIČNOG OKVIRA IZLOŽENOG SEIZMIČKIM DJELOVANJIMA}

Sažetak: U radu su provedene linearne i nelinearne dinamičke analize ovješenog čeličnog okvira izloženog seizmičkim djelovanjima. Razmatrani ovješeni okvir je glavni nosivi sustav sportske hale velikog raspona. S obzirom da dinamička složenost ovješenih konstrukcija rezultira pojavom izrazite geometrijske nelinearnosti, provedene su nelinearna analiza primjenom vremenskog zapisa i referentna analiza prema europskoj normi - linearna metoda spektra odziva. Analize su provedene za različita seizmička opterećenja s obzirom na spektre odziva za različite tipove tla i odgovarajuće umjetno generirane akcelerograme. Također, unatoč temeljnim razlikama između dviju korištenih metoda analize, rezultati ukazuju da je modalna analiza spektra odziva iznenađujuće konzistentna u pogledu raspodjele unutarnjih sila u odnosu na nelinearnu, primjenom vremenskog zapisa. Međutim, analizom spektra odziva dobivene su bitno manje vrijednosti momenata savijanja, unutarnjih sila i pomaka.

Ključne riječi: nelinearnost; seizmička analiza; spektar odziva; vremenski zapis; ovješeni čelični okvir 


\section{INTRODUCTION}

Although geometric nonlinearity is negligible for most types of structures, it has greater impact on cable-stayed structures. The dynamic behavior of cable-stayed structures is complex and is a result of significant geometric nonlinearity, mostly because of cable sag and cable-pylon interaction [1, 2]. One minor reason for the complexity is the slenderness of the pylon (i.e., a beam-column effect).

In this study, displacements and internal forces of a cable-stayed frame structure are evaluated using linear and non-linear dynamic analyses. A cable-stayed frame is the main supporting structure of a wide-span sports hall preliminarily designed by MacGinley [3] and Đuran [4]. An axonometric view of the entire structure and the analyzed cable-stayed frame, as a simplification of the entire structure with locations of lateral restraints, are shown in Figure 1.
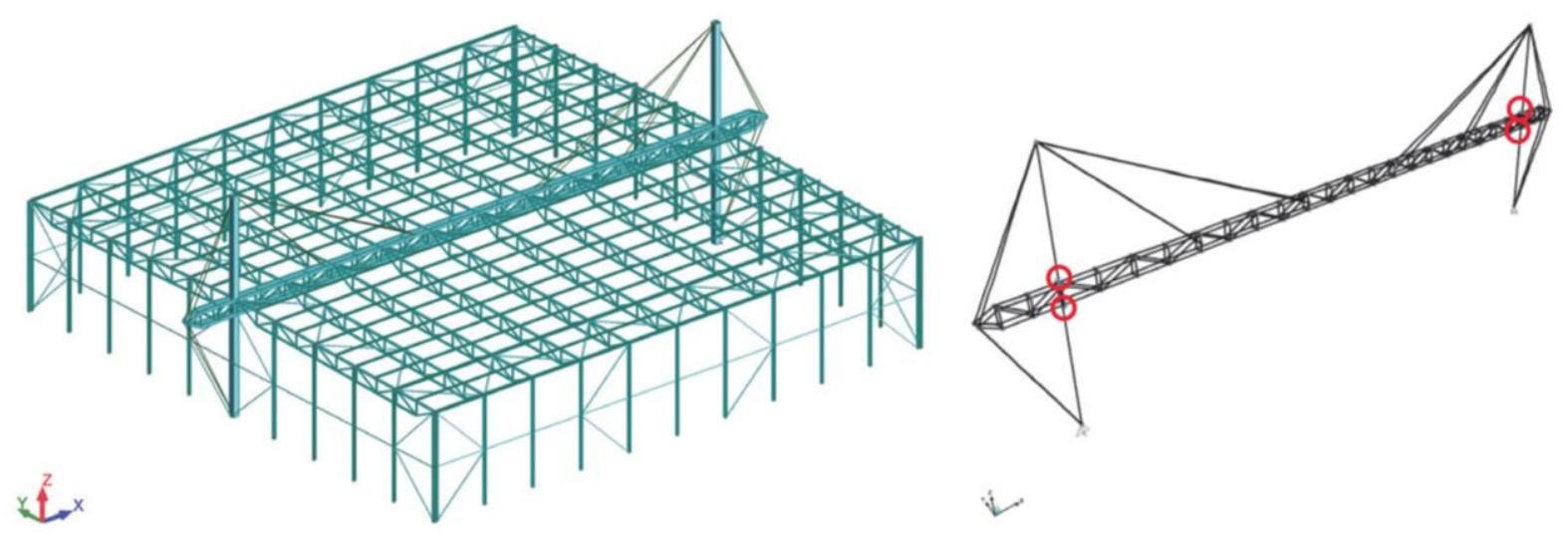

Figure 1 Axonometric view of the entire building and the analyzed cable-stayed frame

Because of the significant nonlinear behavior of the cables, results of different seismic analyses of the cablestayed frame are compared. The results are derived from a modal response spectrum (RS) analysis and a time history $(\mathrm{TH})$ analysis. The former method is a linear analysis approach while the latter is nonlinear; however, both methods are dynamic analyses and are conducted for different seismic actions regarding different ground types. In this article, possible advantages and disadvantages of each method are assessed.

A prime interest of these numerical analyses is the fact that European Standards EN 1998-2 [5] and EN 19986 [6] permit design of cable-stayed structures using the modal RS analysis. However, the feasibility of the RS analysis should be investigated since several papers and researches have indicated that the nonlinear TH analysis results in greater values of displacements and internal forces [7, 8].

\section{NONLINEARITY OF STRUCTURES}

Nonlinearity of structures can be caused by the following sources: material nonlinearity, geometric nonlinearity, and nonlinearity of boundary conditions. In the case of this this cable-stayed structure, the main source of nonlinearity is the cables. They exhibit geometric nonlinearity, which means that axial deformations of the cable have a nonlinear response to axial loading alterations. This is the reason why there is a significant difference in the structure's global stiffness when unloaded and loaded structures are compared, and this is why geometric nonlinearity should be taken into account for dynamic analyses and credibility of the final results $[8,9]$.

One of the challenges analyzing the present structure is its classification into a certain group of structures. This is important because it directly affects the approach to the problem of nonlinearity. Due to the different kinds of elements forming the structure, classifying it into only one group was difficult. For this reason, it was classified as a combination of a suspended bridge and a guyed mast and, consequently, parts of European Standards regarding these two types of structures were used (EN 1998-2 [5] and EN 1998-6 [6]). 


\section{SEISMIC ANALYSIS METHODS}

European Standard EN 1998-1 [10] provides four types of seismic analyses: linear static analysis (lateral force method), linear dynamic analysis (modal response spectrum analysis), nonlinear static analysis (pushover analysis), and non-linear dynamic analysis (time history).

Each of these methods is applicable for assessment of specific structures. Usually, the main parameters for choosing a specific method are the structure's simplicity or complexity, the regularity in its plan and elevation, and its linear or nonlinear behavior.

Since the scope of this article is primarily to compare results given by the modal RS analysis and the $\mathrm{TH}$ analysis, neither of them will be explained in detail and only their main characteristics will be described in the next section.

\section{DESCRIPTION OF PERFORMED ANALYSES}

\subsection{Geometry of cable-stayed structure}

\subsubsection{Elements of pylons and lattice girder}

The analyzed structure is made out of $23.3 \mathrm{~m}$ high pylons with a steel welded square hollow cross section (SHS $620 \times 620 \times 35 \mathrm{~mm}$ ). The spatial lattice girder is made out of two plane lattice girders. Chords are hot finished steel SHS $260 \times 260 \times 14.2 \mathrm{~mm}$ members, diagonal members are SHS $120 \times 120 \times 8 \mathrm{~mm}$, and vertical members as well as horizontal members that join two planar lattice girders are SHS $100 \times 100 \times 8 \mathrm{~mm}$. There are also vertical SHS $260 \times 180 \times 10 \mathrm{~mm}$ tie members at the points where cables were anchored to the lattice girder.

The span of the girder is $60 \mathrm{~m}$ and there is a $6 \mathrm{~m}$ cantilever on each side of the pylon, which gives a total length of the lattice girder of $72 \mathrm{~m}$, with a height of $1.5 \mathrm{~m}$, and a width of $0.75 \mathrm{~m}$. All the elements and their geometric and material characteristics are listed in Table 1.

Table 1 Geometric and material characteristics of lattice girder elements

\begin{tabular}{ccccc}
\hline Elements & Cross section [mm] & Steel grade & Modulus of elasticity [MPa] & Poisson's ratio \\
\hline Pylons & $620 \times 620 \times 35$ & S355 & 210000 & 0.3 \\
\hline Chords & $260 \times 260 \times 14.2$ & S355 & 210000 & 0.3 \\
\hline Diagonal bracing & $120 \times 120 \times 8$ & S355 & 210000 & 0.3 \\
\hline $\begin{array}{c}\text { Vertical and horizontal } \\
\text { bracing }\end{array}$ & $100 \times 100 \times 8$ & S355 & 210000 & 0.3 \\
\hline Cable tie member & $260 \times 180 \times 10$ & S355 & 210000 & 0.3 \\
\hline
\end{tabular}

\subsubsection{Cables}



Figure 2 Positions of cables 
Cable positions are shown in Figure 2. Cables 1 and 2 are located within the span of the lattice girder and are made out of steel locked coil strands with a diameter of $45 \mathrm{~mm}$. Its design tensile strength is $1212 \mathrm{kN}$. Cables at position 1 are $23 \mathrm{~m}$ long and cables at position 2 are $16 \mathrm{~m}$ long. Cables at position 3 are $13 \mathrm{~m}$ long, connecting the far end of the lattice girder, at the end of a cantilever, with the bottom and top of the pylon. They are made out of steel locked coil strands with a diameter of $80 \mathrm{~mm}$. The design tensile strength is $3873 \mathrm{kN}$.

Table 2 Geometrical and material characteristics of cables [11]

\begin{tabular}{cccccc}
\hline Elements & $\begin{array}{c}\text { Cross section } \\
{[\mathrm{mm}]}\end{array}$ & $\begin{array}{c}\text { Nominal axial } \\
\text { stiffness [MN] }\end{array}$ & $\begin{array}{c}\text { Nominal metallic } \\
\text { cross section }\left[\mathrm{mm}^{2}\right]\end{array}$ & $\begin{array}{c}\text { Nominal metallic } \\
\text { mass }[\mathrm{kg} / \mathrm{m}]\end{array}$ & $\begin{array}{c}\text { Design tensile } \\
\text { strength }[\mathrm{kN}]\end{array}$ \\
\hline Cables 1,2 & $\varnothing 45$ & 229 & 1390 & 11,1 & 1212 \\
\hline Cable 3 & $\varnothing 80$ & 729 & 4420 & 35,5 & 3873 \\
\hline
\end{tabular}

The geometrical and material characteristics of cables are shown in Table 2. Generally, cables play a key role in cable-stayed structures because of the nonlinear relationship between the cable tensile force and the corresponding stretch of the cable - cable sag effect. To allow for this cable sag effect according to [12, 13], two approaches can be used. In the first one, each cable is replaced by one truss element with equivalent modulus of elasticity [13]. The second approach is to use cable elements, which can be straight or curved by using one or several elements to model the cable. Unlike the second approach, the first approach cannot model the transverse vibrations of the cables; therefore, in this study, the second approach has been applied by using SAP2000 [14]. From the values of nominal axial stiffness and nominal metallic cross section given in Table 2, a modulus of 165000 $\mathrm{MPa}$ for the cables was calculated and used to model cable elements. Additionally, a small difference in the initial pretension force of a cable can have a significant effect on the cable sag and tautness and therefore, on the global stiffness and overall stability of the structure. However, the initial pretension was set to around $10 \%$ of the design tensile force, as is recommended by $[8,9,14]$.

\subsection{Definition of seismic action}

\subsubsection{Response spectra}

For the seismic analysis, horizontal and vertical response spectra were used in accordance with EN 1998-1 [10]. Both horizontal and vertical spectra are type 1, which means that the surface-wave magnitude is greater than Ms $=5.5$. For horizontal actions, analyses were conducted for each of the following three ground types: $A, C$, and $E$ according to EN 1998-1 [10]. All of the spectra are design response spectra with a behavior factor $q=1.5$. Vertical spectra are independent of the ground type because the European Standard does not differentiate vertical spectra for different ground types.

Response spectra are shown in Figure 3 using a ground acceleration of $0.3 \mathrm{~g}$ for all spectra. It should be noted that the response spectra for ground types $E$ and $A$ result in the highest and lowest ordinate, respectively.

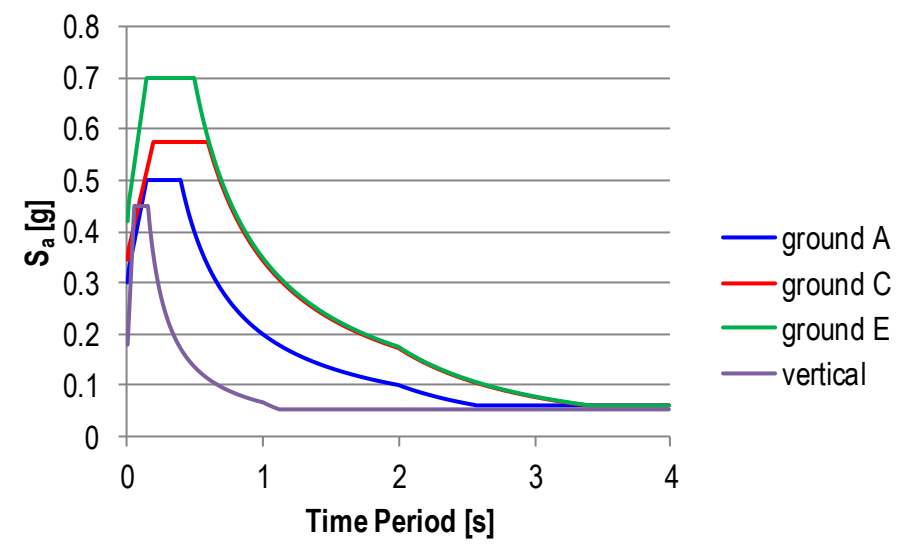

Figure 3 Response spectra for ground types A, C, and E and vertical response spectra 


\subsubsection{Accelerograms}

Accelerograms were artificially generated with SeismoArtif [15]. Accelerograms were matched to comply with elastic response spectra for a ground acceleration of $0.3 \mathrm{~g}$ with a viscose damping of $5 \%$ for ground types $\mathrm{A}, \mathrm{C}$, and $\mathrm{E}$ in two horizontal directions and with vertical response spectra for the vertical direction. Records are divided into 0.01 $\mathrm{s}$ time intervals within a total duration of $20 \mathrm{~s}$. Generated accelerograms are shown in Figures 4-6.

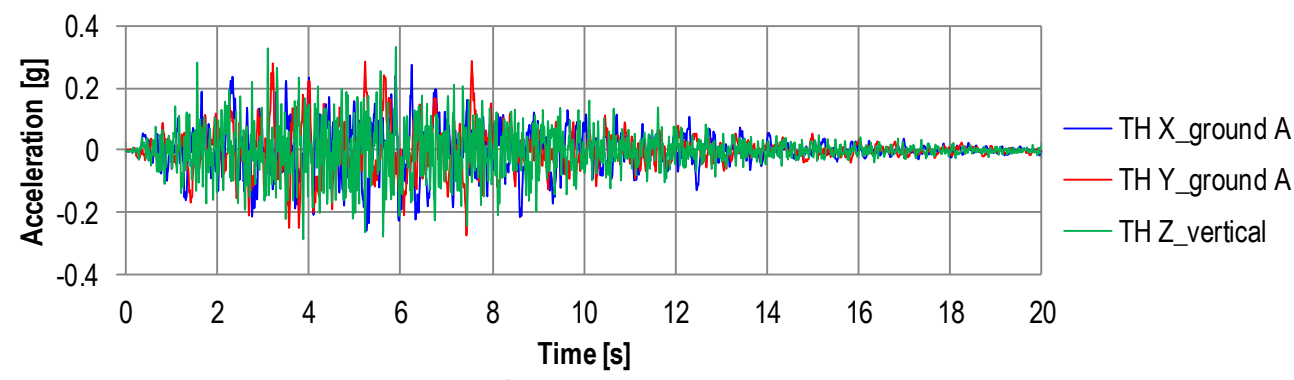

Figure 4 Accelerograms for ground type $A$ in the $x, y$, and $z$ directions



Figure 5 Accelerograms for ground type $C$ in the $x, y$, and $z$ directions

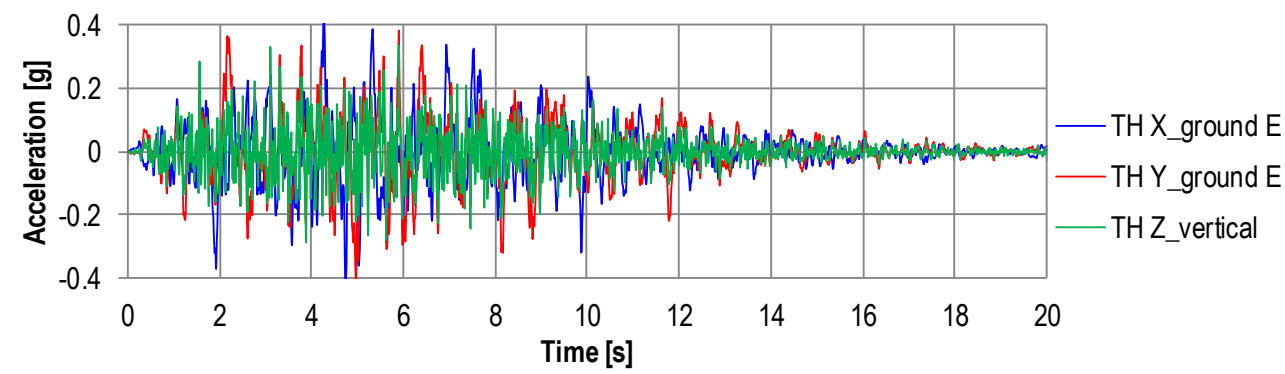

Figure 6 Accelerograms for ground type $E$ in the $x, y$, and $z$ directions

\subsection{Performed analyses}

\subsubsection{Static analysis}

For static analysis, the following static loads were applied to the structure: the self-weight of the elements and reactions from the self-weight of the roof lattice girders and their installations. All loads were defined as linear static loads and are shown in Table 3, while positions of applied loads are shown in Figure 7.

Table 3 Static load cases applied as reactions from roof lattice girders

\begin{tabular}{cccc}
\hline Load case name & Type & Value 1 [kN] & Value 2 [kN] \\
\hline Self-weight - roof lattice girders & Permanent & 11.63 & 5.82 \\
\hline Additional load & Permanent & 16.32 & 8.16 \\
\hline Installations & Permanent & 45 & 22.5 \\
\hline
\end{tabular}




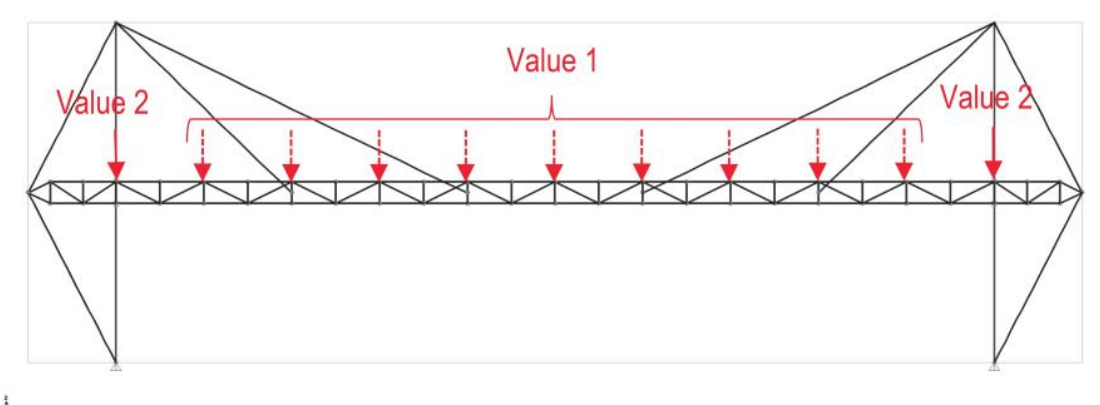

Figure 7 Positions of applied loads as reactions from roof lattice girders

Cables were modelled with SAP2000 [14] cable elements, which use an elastic catenary formulation to represent the behavior of a slender cable under its own self-weight, temperature, and strain loading. This behavior is non-linear and inherently includes the tension - stiffening (P-delta) effect [14]. Initial pretension forces in cables were defined with the Target Force option in [14]. The load case containing Target Force loads and already mentioned static forces was defined as a static nonlinear load. Pretension forces in cables 1,2, and 3 were defined as $10 \%$ of the cables' ultimate design tensile strengths with values $106 \mathrm{kN}, 112 \mathrm{kN}$, and $394 \mathrm{kN}$, respectively. After performing the static analysis, the resulting axial forces in cables 1,2 , and 3 were $225 \mathrm{kN}, 325 \mathrm{kN}$, and $1173 \mathrm{kN}$, respectively.

The influence of cable discretization was analyzed by two different models of the structure. The mass contributed by the cable element in the first model was lumped at the cable ends to reduce the number of modal shapes. The influence of discretized cables was investigated in the second model by comparing modal shapes and modal participating masses, as shown in Table 5. It was concluded that individual cable vibrations changed the overall dynamic behavior of the structure by the interaction of the cables and the structure and the model with discretized cables was selected for further analyses. In papers [13] and [16], a similar conclusion was obtained.

A partial factor for all loads was $\gamma=1$, in compliance with EN 1990 [17] for accidental seismic actions. All static and dynamic analyses were performed using the SAP 2000 v.17 computer software [14].

\subsubsection{Modal response spectrum analysis}

The modal response spectrum analysis was conducted after all static loads and pretension forces were applied to the structure. In other words, the analysis was carried out from a deformed initial state of the structure. The analysis was conducted for three ground types (A, C, and E) with a total of 200 calculated modal shapes. This number of modes was required in order to satisfy the criterion that the sum of the participating mass should be equal or larger than $90 \%$ of the total mass and all modes with effective modal masses greater than $5 \%$ of the total mass to be taken into account. Because coupled modes with closely spaced periods, the combination method CQC (Complete Quadratic Combination) was used to calculate the modal superposition [10].

\subsubsection{Time history analysis}

A nonlinear dynamic analysis was conducted with a time integration method. Equilibrium differential equations were integrated in every time interval using Newmark's method with coefficients $\gamma=0.5$ and $\beta=0.25$ [14]. These values ensured that the analysis is numerically unconditionally stable without energy dissipation [14, 18]. Taking into account a large displacement and P- $\Delta$ effects, complete geometric nonlinearity is ensured. Possible problems regarding the convergence of the analysis were diminished by choosing a time interval of $0.001 \mathrm{~s}[8,14]$.

An important component for dynamic analysis of structures with multiple degrees of freedom is damping and the most common approach is to implement it through equivalent Rayleigh damping [9] given by

$C=\alpha M+\beta K$,

where $C, M$, and $K$ are damping, mass, and stiffness matrices, respectively, and $\alpha$ and $\beta$ are coefficients representing mass and stiffness proportional damping, respectively. The mass damping coefficient is linearly

Đuran, M, Lukačević, I, Dujmović, D 
proportional to the period of vibrations and the stiffness proportional damping is linearly proportional to the structure's frequency. Therefore, modal analysis is necessary for studying the dynamic behavior of cable-stayed structures. Damping coefficients are calculated from expressions:

$$
\begin{aligned}
& \alpha=\xi \frac{2 \omega_{1} \omega_{2}}{\omega_{1}+\omega_{2}} \\
& \beta=\xi \frac{2}{\omega_{1}+\omega_{2}},
\end{aligned}
$$

where $\xi$ is the damping of the structure and $\omega_{1}$ and $\omega_{2}$ are the frequency values at either end of the range containing modes of $5 \%$ or more of the participating modal mass, respectively.

The obtained damping was used to damp modes with high frequencies that contain a small percentage of the participating mass. These modes do not have a significant influence on the behavior of the structure but their damping contributes to the convergence of the analysis.

\section{RESULTS AND DISCUSSION}

Nonlinear TH analysis and linear modal RS analysis were conducted in this research and the results were used to estimate and predict responses of a cable-stayed frame for various seismic actions. In addition, results from both types of analyses and responses of the structure were compared. The results of modal analysis were used in order to calculate coefficients for equivalent Rayleigh damping.

Table 5 shows the modal analysis results with all the calculated modes containing $5 \%$ or more of participating modal mass and their periods and frequencies for a model with a lumped mass of cables at the cable ends and a model with discretized cables. The results for the model with a lumped mass of cables are shown in brackets in Table 5.

Table 5 Modes with $5 \%$ or more of participating modal mass and their periods and frequencies

\begin{tabular}{ccccc}
\hline Mode number & Direction & Period [s] & Frequency [Hz] & $\begin{array}{c}\text { Modal effective mass } \\
\text { ratio }\end{array}$ \\
\hline $3(3)$ & $\mathrm{x}$ & $0.966(0.967)$ & $1.035(1.034)$ & $0.908(0.910)$ \\
\hline $19(11)$ & $\mathrm{x}$ & $0.346(0.348)$ & $2.890(2.874)$ & $0.079(0.084)$ \\
\hline $1(1)$ & $\mathrm{y}$ & $3.050(3.053)$ & $0.328(0.328)$ & $0.720(0.720)$ \\
\hline $5(5)$ & $\mathrm{y}$ & $0.830(0.831)$ & $1.205(1.203)$ & $0.083(0.083)$ \\
\hline $10(10)$ & $\mathrm{y}$ & $0.400(0.398)$ & $2.500(2.512)$ & $0.033(0.062)$ \\
\hline $32(17)$ & $\mathrm{y}$ & $0.204(0.203)$ & $4.902(4.926)$ & $0.027(0.055)$ \\
\hline $4(4)$ & $\mathrm{z}$ & $0.841(0.842)$ & $1.189(1.188)$ & $0.570(0.570)$ \\
\hline $33(16)$ & $\mathrm{z}$ & $0.204(0.204)$ & $4.902(4.902)$ & $0.073(0.081)$ \\
\hline $81(25)$ & $\mathrm{z}$ & $0.097(0.099)$ & $10.309(10.101)$ & $0.042(0.049)$ \\
\hline $157(61)$ & $\mathrm{z}$ & $0.034(0.035)$ & $29.412(28.571)$ & $0.249(0.250)$ \\
\hline
\end{tabular}

Coefficients for Rayleigh damping were calculated from frequencies shown in Table 5 . Modes with $5 \%$ or more of the participating modal mass are modes $1-157$. Therefore, the frequencies of modes 1 and 157 are taken as the boundary values for Eqs. (2) and (3), which gives $\alpha=0.032437$ and $\beta=0.003369$.

Figure 8 shows characteristic mode shapes with the largest percentage of participating mass for each direction of seismic action. 


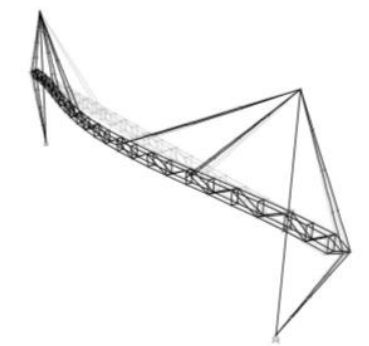

(a) Mode shape 1, y direction

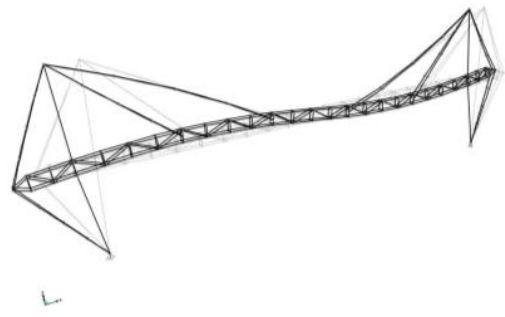

(b) Mode shape $3, x$ direction

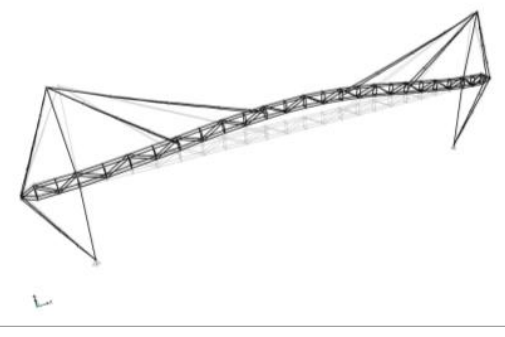

(c) Mode shape 4, $z$ direction

Figure 8 Mode shapes 1,3 , and 4

Figure 9 shows nodes and directions for which displacements were analyzed and compared.

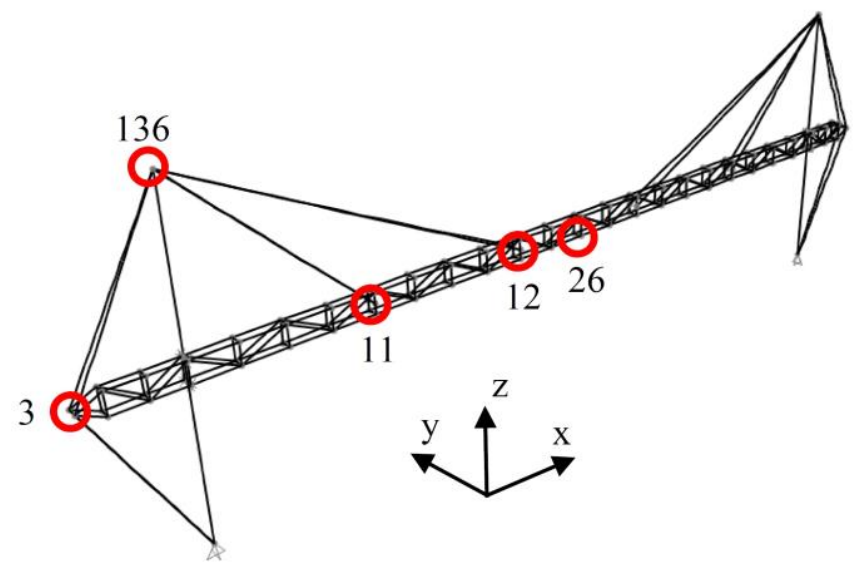

Figure 9 Observed nodes and directions

The following tables present results from the nonlinear TH and linear modal RS analyses for node displacements, axial forces in cables, bending moments in pylons, and base reactions. Tables 6,7 , and 8 show maximum absolute displacements from the TH and RS analyses and the comparison ratio between the TH and RS results $(T H / R S)$ for ground types $A, C$, and $E$, respectively.

Table 6 Comparison of displacements along the $x, y$, and $z$ directions for ground $A$

\begin{tabular}{|c|c|c|c|c|c|c|c|}
\hline Node & Analysis & $x[\mathrm{~m}]$ & TH/RS & $y[\mathrm{~m}]$ & TH/RS & $\mathrm{z}[\mathrm{m}]$ & TH/RS \\
\hline \multirow{2}{*}{3} & $\mathrm{TH}$ & 0.097 & \multirow{2}{*}{1.38} & 0.037 & \multirow{2}{*}{1.33} & 0.037 & \multirow{2}{*}{1.34} \\
\hline & RS & 0.071 & & 0.028 & & 0.027 & \\
\hline \multirow{2}{*}{11} & $\mathrm{TH}$ & 0.094 & \multirow{2}{*}{1.43} & 0.153 & \multirow{2}{*}{1.12} & 0.106 & \multirow{2}{*}{0.92} \\
\hline & RS & 0.065 & & 0.137 & & 0.116 & \\
\hline \multirow{2}{*}{12} & $\mathrm{TH}$ & 0.098 & \multirow{2}{*}{1.41} & 0.260 & \multirow{2}{*}{1.05} & 0.162 & \multirow{2}{*}{0.81} \\
\hline & RS & 0.069 & & 0.247 & & 0.200 & \\
\hline \multirow{2}{*}{26} & $\mathrm{TH}$ & 0.095 & \multirow{2}{*}{1.45} & 0.267 & \multirow{2}{*}{1.04} & 0.161 & \multirow{2}{*}{0.77} \\
\hline & RS & 0.065 & & 0.256 & & 0.210 & \\
\hline \multirow{2}{*}{136} & $\mathrm{TH}$ & 0.171 & \multirow{2}{*}{1.18} & 0.032 & \multirow{2}{*}{1.20} & 0.006 & \multirow{2}{*}{0.87} \\
\hline & RS & 0.145 & & 0.026 & & 0.007 & \\
\hline
\end{tabular}


Linear and non-linear analyses of cable-stayed steel frame subjected to seismic actions

Table 7 Comparison of displacements along the $x, y$, and $z$ directions for ground $C$

\begin{tabular}{|c|c|c|c|c|c|c|c|}
\hline Node & Analysis & $x[\mathrm{~m}]$ & TH/RS & $\mathrm{y}[\mathrm{m}]$ & TH/RS & $\mathbf{z}[\mathrm{m}]$ & TH/RS \\
\hline \multirow{2}{*}{3} & $\mathrm{TH}$ & 0.176 & \multirow{2}{*}{1.52} & 0.046 & \multirow{2}{*}{1.25} & 0.069 & \multirow{2}{*}{1.53} \\
\hline & RS & 0.116 & & 0.037 & & 0.045 & \\
\hline \multirow{2}{*}{11} & $\mathrm{TH}$ & 0.172 & \multirow{2}{*}{1.55} & 0.200 & \multirow{2}{*}{1.17} & 0.133 & \multirow{2}{*}{0.99} \\
\hline & RS & 0.111 & & 0.171 & & 0.135 & \\
\hline \multirow{2}{*}{12} & $\mathrm{TH}$ & 0.172 & \multirow{2}{*}{1.48} & 0.331 & \multirow{2}{*}{1.09} & 0.180 & \multirow{2}{*}{0.86} \\
\hline & RS & 0.117 & & 0.305 & & 0.210 & \\
\hline \multirow{2}{*}{26} & $\mathrm{TH}$ & 0.176 & \multirow{2}{*}{1.56} & 0.338 & \multirow{2}{*}{1.07} & 0.161 & \multirow{2}{*}{0.77} \\
\hline & RS & 0.113 & & 0.317 & & 0.210 & \\
\hline \multirow{2}{*}{136} & $\mathrm{TH}$ & 0.300 & \multirow{2}{*}{1.40} & 0.050 & \multirow{2}{*}{1.56} & 0.008 & \multirow{2}{*}{1.04} \\
\hline & RS & 0.214 & & 0.032 & & 0.008 & \\
\hline
\end{tabular}

Table 8 Comparison of displacements along the $x, y$, and $z$ directions for ground $E$

\begin{tabular}{|c|c|c|c|c|c|c|c|}
\hline Node & Analysis & $x[\mathrm{~m}]$ & TH/RS & $y[\mathrm{~m}]$ & TH/RS & $z[\mathrm{~m}]$ & TH/RS \\
\hline \multirow{2}{*}{3} & $\mathrm{TH}$ & 0.178 & \multirow{2}{*}{1.51} & 0.048 & \multirow{2}{*}{1.28} & 0.069 & \multirow{2}{*}{1.52} \\
\hline & RS & 0.117 & & 0.038 & & 0.046 & \\
\hline \multirow{2}{*}{11} & TH & 0.174 & \multirow{2}{*}{1.55} & 0.204 & \multirow{2}{*}{1.17} & 0.134 & \multirow{2}{*}{0.99} \\
\hline & RS & 0.113 & & 0.174 & & 0.136 & \\
\hline \multirow{2}{*}{12} & $\mathrm{TH}$ & 0.174 & \multirow{2}{*}{1.47} & 0.337 & \multirow{2}{*}{1.09} & 0.182 & \multirow{2}{*}{0.86} \\
\hline & RS & 0.118 & & 0.309 & & 0.210 & \\
\hline \multirow{2}{*}{26} & $\mathrm{TH}$ & 0.178 & \multirow{2}{*}{1.56} & 0.346 & \multirow{2}{*}{1.08} & 0.162 & \multirow{2}{*}{0.77} \\
\hline & RS & 0.114 & & 0.321 & & 0.210 & \\
\hline \multirow{2}{*}{136} & TH & 0.303 & \multirow{2}{*}{1.40} & 0.061 & \multirow{2}{*}{1.56} & 0.008 & \multirow{2}{*}{1.04} \\
\hline & RS & 0.217 & & 0.039 & & 0.008 & \\
\hline
\end{tabular}

Displacement results of the modal RS analysis in Tables 6-8 show some trends of linear behavior despite the obvious nonlinear behavior of the structure. This linear behavior can be seen from the increase of the displacements regarding the response spectrums for ground types A to E. Comparison of displacement values for both seismic types shows that the largest displacement values are obtained for ground type $E$, while the smallest values are obtained for ground type $A$. This relation is actually expected and could have been presumed from the shapes of the response spectra curves, even before conducting the analyses. Regarding the comparison of the results from the two different types of analysis, it is apparent that displacements from the modal RS analysis are significantly lower than those from the $\mathrm{TH}$ analysis.

Table 9 Comparison of axial forces F1, F2, and F3 in cables 1, 2 and 3, respectively, for grounds $A, C$, and E.

\begin{tabular}{c|ccc|ccc|ccc}
\hline & \multicolumn{3}{|c|}{ TH Analysis } & \multicolumn{3}{c|}{ RS Analysis } & \multicolumn{3}{c}{ Ratio TH/RS } \\
\hline & F1 [kN] & F2 [kN] & F3 [kN] & F1 [kN] & F2 [kN] & F3 [kN] & F1 & F2 & F3 \\
\hline Ground A & 493 & 427 & 1832 & 334 & 372 & 1429 & 1.48 & 1.15 & 1.28 \\
\hline Ground C & 687 & 526 & 2275 & 408 & 386 & 1608 & 1.68 & 1.36 & 1.42 \\
\hline Ground E & 687 & 525 & 2283 & 411 & 390 & 1616 & 1.67 & 1.35 & 1.41 \\
\hline
\end{tabular}

For cables 1, 2, and 3, shown in Figure 2, the axial forces for TH and RS analyses and their ratios are displayed in Table 9. From the comparison of tension axial forces in the table with the static axial forces in the cables presented in Section 4.3.1, it is noticeable that there is an increase of more than 3 times in the forces due to seismic actions in comparison to forces when only static and pretension forces are applied. However, the increases in the force values do not reach the ultimate resistance values of these elements (shown in Table 2). 
Furthermore, Table 9 clearly shows that forces from the modal RS analysis are in average around $40 \%$ of the value of forces from TH analysis. As was the case with displacements, predominant seismic forces are exhibited for ground $\mathrm{E}$.

Figure 10 shows pylon nodes 124 and 126. Node 126 is located in a region with the largest bending moment about the $y-y$ axis (in the frame plane) while node 124 is located in a region with the largest bending moment about the $z-z$ axis (out of the frame plane).

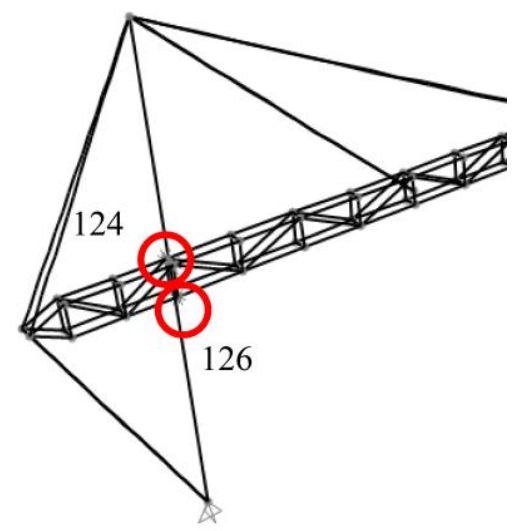

Figure 10 Nodes with maximum bending moments

Table 10 shows calculated maximum bending moments at nodes 124 and 126 and Table 11 shows base reaction values of the pylons. Both tables show results from $\mathrm{TH}$ and $\mathrm{RS}$ analyses and their ratio.

Table 10 Bending moment around axis $y-y$ and $z-z$ at nodes 126 and 124 and their ratio for grounds A, C, and $E$.

\begin{tabular}{c|cc|cc|cc}
\hline & \multicolumn{2}{|c|}{ TH Analysis } & \multicolumn{2}{c|}{ RS Analysis } & \multicolumn{2}{c}{ Ratio TH/RS } \\
\hline & $\begin{array}{c}\text { My-y } \\
{[\mathrm{kN} \mathrm{m}]}\end{array}$ & $\begin{array}{c}\text { Mz-z } \\
{[\mathrm{kN} \mathrm{m}]}\end{array}$ & $\begin{array}{c}\text { My-y } \\
{[\mathrm{kN} \text { m }]}\end{array}$ & $\begin{array}{c}\text { Mz-z } \\
{[\mathrm{kN} \mathrm{m}]}\end{array}$ & My-y & Mz-z \\
\hline Ground A & 1143 & 529 & 761 & 356 & 1.50 & 1.49 \\
\hline Ground C & 949 & 891 & 971 & 430 & 0.98 & 2.07 \\
\hline Ground E & 1156 & 797 & 982 & 522 & 1.18 & 1.53 \\
\hline
\end{tabular}

Table 11 Base reactions and their comparison for grounds $\mathrm{A}, \mathrm{C}$, and $\mathrm{E}$.

\begin{tabular}{c|ccc|ccc|ccc}
\hline & \multicolumn{3}{|c|}{ TH Analysis } & \multicolumn{3}{c|}{ RS Analysis } & \multicolumn{3}{c}{ Ratio TH/RS } \\
\hline & Fx [kN] & Fy [kN] & Fz [kN] & Fx [kN] & Fy [kN] & Fz [kN] & Fx & Fy & Fz \\
\hline Ground A & 1076 & 263 & 3407 & 522 & 129 & 3163 & 2.06 & 2.04 & 1.08 \\
\hline Ground C & 1878 & 305 & 3386 & 888 & 165 & 3163 & 2.11 & 1.84 & 1.07 \\
\hline Ground E & 1893 & 342 & 3409 & 905 & 179 & 3163 & 2.09 & 1.91 & 1.08 \\
\hline
\end{tabular}

Regarding the comparison of the results for different grounds, conclusions can be drawn that results for ground type $E$ have the largest values, while results for ground type $A$ are the smallest. However, results for bending moments around the $y$-y axis in pylons at node 126 (see Figure 10 and Table 10) show that ground type $C$ gives the smallest values of bending moments from the TH analysis.

It is noteworthy that bending moments from the RS analysis are considerably smaller than those from the $\mathrm{TH}$ analysis, especially for node 124 (z-z axis, Table 10). The bending moments differences for node 126 (y-y axis Table 10) are somewhat smaller, but still significant. The same tendency can be seen for base reactions results (Table 11), where forces from the TH analysis can be more than $100 \%$ larger than those from the RS analysis. These differences should be investigated in more detail in future studies. However, the distributions of bending moments and shear forces are very similar in both nonlinear and linear analyses. 


\section{CONCLUSIONS}

In this study, linear and non-linear dynamic analyses of a cable-stayed steel frame subjected to seismic actions were performed.

According to European standards, linear and non-linear dynamic analyses are recommended for the type of structure analyzed in this article. However, comparing the results from the two different types of analysis, it is apparent that forces and bending moments from the modal response spectrum analysis are significantly smaller than those from the time history analysis. Results of the modal response spectrum analyses for different ground types have shown some trends of a linear behavior despite the obvious nonlinear behavior of the structure. Additionally, despite fundamental differences between the two methods of analysis, results indicate that the internal forces and bending moment distributions from the modal response spectrum analysis is surprisingly consistent with those from the nonlinear time history analysis.

Future research should set its goals on analyzing several structures of this type and investigate tendencies that appear with different heights and span lengths in relation to different acceleration values, different positions of dead loads, and cable diameters - pretension forces. In addition, further research should consider the effect of wind action, which can be of great importance for the type of structure analyzed.

\section{References}

[1] Kim, S.; Won, D.H.; Lee, K.; Kang, Y.J. 2015: Structural Stability of Cable-stayed Bridges, International Journal of Steel Structures, 15, pp. 743-60, https://doi.org/10.1007/s13296-015-9019-1

[2] El Ouni, M.H.; Ben Kahla, N.; Preumont, A. 2012: Numerical and experimental dynamic analysis and control of a cable stayed bridge under parametric excitation, Engineering Structures, 45, pp. 244-56, https://doi.org/10.1016/i.engstruct.2012.06.018

[3] MacGinley, T.J. 2002: Steel Structures: Practical Design Studies, 2nd edition, Suffolk, CRC Press Book, Great Britain

[4] Đuran, M. 2015: Design of wide span structure with cable-stayed frame, Master thesis, University of Zagreb

[5] EN 1998-2: 2005: Eurocode 8: Design of structures for earthquake resistance - Part 2: Bridges, Bruxelles, Belgium: European Committee for Standardization

[6] EN 1998-6: 2005: Eurocode 8: Design of structures for earthquake resistance - Part 6: Towers, masts and chimneys, Bruxelles, Belgium: European Committee for Standardization

[7] Causevic, M.; Mitrovic, S. 2011: Comparison between non-linear dynamic and static seismic analysis of structures according to European and US provisions, Bulletin of Earthquake Engineering, 9, pp. 467-89, https://doi.org/10.1007/s10518-010-9199-1

[8] Grey, M. 2006: Finite Elements Seismic Analysis of Guyed Masts, Master Thesis, University of Oxford

[9] Blakeborough, A.; Grey, M.; Williams, M.S. 2008: Characterizing the Seismic Behavior of Guyed Masts, Journal of Earthquake Engineering, 12, pp. 36-53, https://doi.org/10.1080/13632460701250198

[10] EN 1998-1: 2004: Eurocode 8: Design of structures for earthquake resistance - Part 1: General rules, seismic actions and rules for buildings, Bruxelles, Belgium: European Committee for Standardization

[11] Bridon Structural Systems: Mast Stays and Towers - Stay Cables: Locked Coil Strand: http://www.bridon.com, Accessed 30 July 2015.

[12] Xiao, Y., Zhuo, W. D., \& Fan, L. C. 2011: A Note on the Equivalent Modulus of Elasticity of Stay Cables, Advanced Materials Research, 255-260, pp. 1266-1269, https://doi.org/10.4028/www.scientific.net/AMR.255-260.1266

[13] Au, F. T. K., Cheng, Y. S., Cheung, Y. K., \& Zheng, D. Y. 2001: On the determination of natural frequencies and mode shapes of cable-stayed bridges, Applied Mathematical Modelling, 25 (12), pp. 1099-1115, https://doi.org/10.1016/S0307-904X(01)00035-X

[14] Computers and Structures inc. 2014: CSI Analysis Reference Manual, Berkeley CA

[15] Seismosoft 2014: SeismoArtif - A computer software for artificial generation of earthquake accelerograms

[16] Abdel-Ghaffar, A. M., \& Khalifa, M. A. 1991: Importance of cable vibration in dynamics of cable-stayed bridges, Journal of Engineering Mechanics, 117(11), 2571-2589. https://doi.org/10.1061/(ASCE)07339399(1991)117:11(2571)\#sthash.qvCQRtWC.dpuf

[17] EN 1990: 2002: Eurocode - Basis of structural design, Bruxelles, Belgium: European Committee for Standardization

[18] Wilson, E.L. 2002: Three-Dimensional Static and Dynamic Analysis of Structures, Computers and Structures Inc., Berkeley, CA 